\title{
INTENTION, PRINCIPLE, OUTPUTS AND AIMS OF THE EXPERIMENTAL PAVILION RESEARCH OF BUILDING ENVELOPES INCLUDING WINDOWS FOR WOODEN BUILDINGS
}

\author{
Daniela ŠTAFFENOVÁ ${ }^{1, *}$, Ján RYBÁRIK ${ }^{1}$, Miroslav JAKUBČÍK ${ }^{1}$ \\ ${ }^{1}$ Department of Building Engineering and Urban Planning, Faculty of Civil Engineering, University of \\ Žilina, Univerzitná 1, 01026 Žilina, Slovakia. \\ corresponding author: daniela.staffenova@fstav.uniza.sk
}

\section{Abstract}

The aim of experimental research in the area of exterior walls and windows suitable for wooden buildings was to build special pavilion laboratories. These laboratories are ideally isolated from the surrounding environment, airtight and controlled by the constant internal climate. The principle of experimental research is measuring and recording of required physical parameters (e.g. temperature or relative humidity). This is done in layers of experimental fragment sections in the direction from exterior to interior, as well as in critical places by stable interior and real exterior climatic conditions. The outputs are evaluations of experimental structures behaviour during the specified time period, possibly during the whole year by stable interior and real exterior boundary conditions. The main aim of this experimental research is processing of long-term measurements of experimental structures and the subsequent analysis. The next part of the research consists of collecting measurements obtained with assistance of the experimental detached weather station, analysis, evaluation for later setting up of reference data set for the research locality, from the point of view of its comparison to the data sets from Slovak Hydrometeorological Institute (SHMU) and to localities with similar climate conditions. Later on, the data sets could lead to recommendations for design of wooden buildings.
\end{abstract}

\section{Keywords:}

Pavilion experimental research; Building envelopes of wooden buildings;

Experimental window;

Experimental wall fragment.

\section{Introduction}

The research team of the Department of Building Engineering and Urban Planning started to deal intensively with partial research of building envelope constructions for wooden buildings in lowenergy standard in the year 2008. For this purpose, the laboratory of pavilion type started to be built with support from the structural funds. In the year 2011 this first laboratory of the Department, focused on windows and constructions of building envelope, was put into the operation.

In the year 2016, there was given one more room to the laboratory, within solving the project from structural funds "Research Centre of University of Žilina". After this change, at present our laboratory has two separate rooms with adjustable stable conditions of indoor environment for building envelope constructions and one room for research of windows.

\section{The research in original laboratory centre of pavilion type}

The original first laboratory centre consisted of two specialized air-conditioned rooms of pavilion type with entrance hall and service office with the measuring equipment.

As part of the measuring device, the weather station was placed on the roof of the building.

Interior walls of both laboratory pavilions, external wall with the experimental wall fragment for wooden buildings and three windows, ceiling and floor were fitted with insulation, so that the heat losses are minimized and the airtightness is ensured. The laboratory was focused on window research 
and sandwich construction of external wall of wooden building with pillar structure, in stable interior conditions regulated by the air conditioning units and exposed to the real exterior boundary conditions, which are recorded by the weather station.

The research in such laboratory centre was conducted for five years and its results were continuously published. The laboratory centre also was used like an illustration of Department research for educational purposes.

The window research in pavilion laboratory is done continuously according to the original standard even now. The basic dimension of the space for placement of experimental window is $1250 \times$ $1500 \mathrm{~mm}$. Window structure samples consist of various material basis with various glazing. Two windows are based on 6-chamber plastic profiles Rehau. One window has thermal modules in its profiles. The third window is a wooden one, from euro profiles. All three windows have triple glazing. The windows are fixed in such way that along their perimeter there are no thermal bridges. Views from interior at the windows fixed in external wall are in the Fig. 1 combined with samples of cut frame. Figure 2 shows sensors, which are connected to the switchboard by cables. Figure 3 shows graphically processed results from measurement for publication.
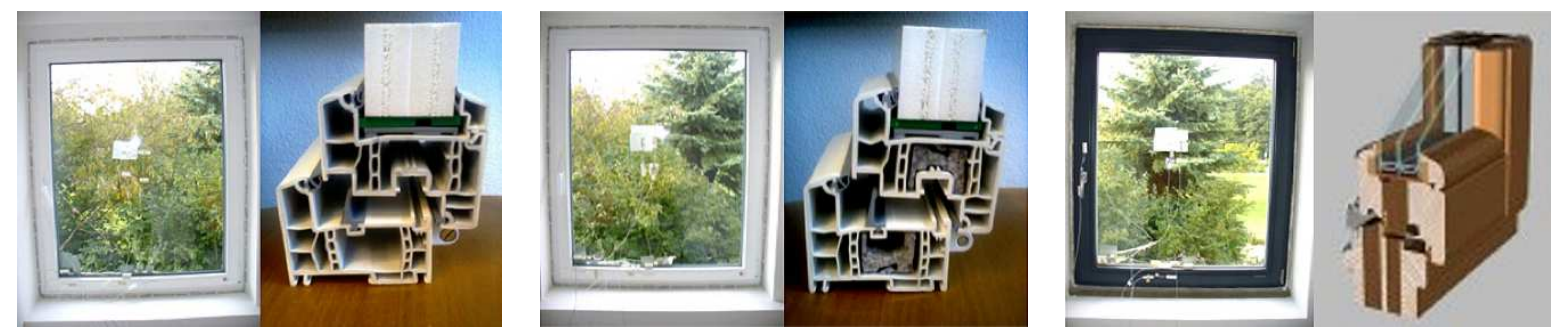

Fig. 1: Interior view of the windows in the building envelope of the pavilion with cuts of frames [9].
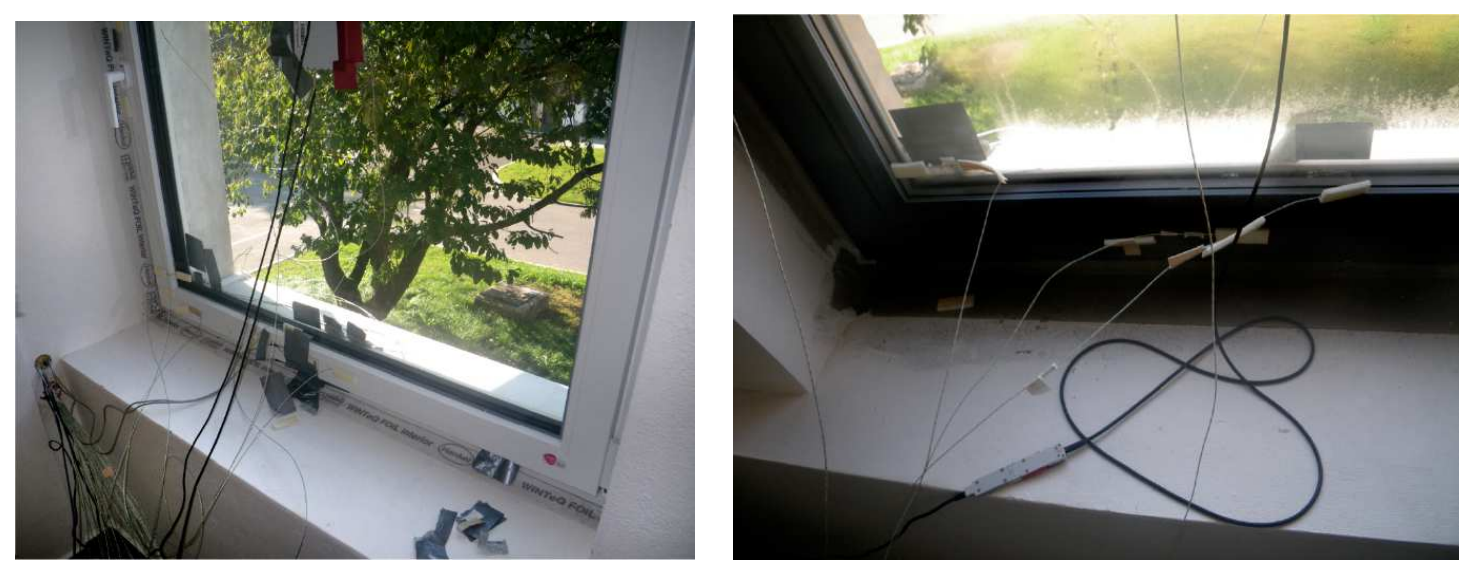

Fig. 2: View of the sensors on the windows connected to the control panel by cables.

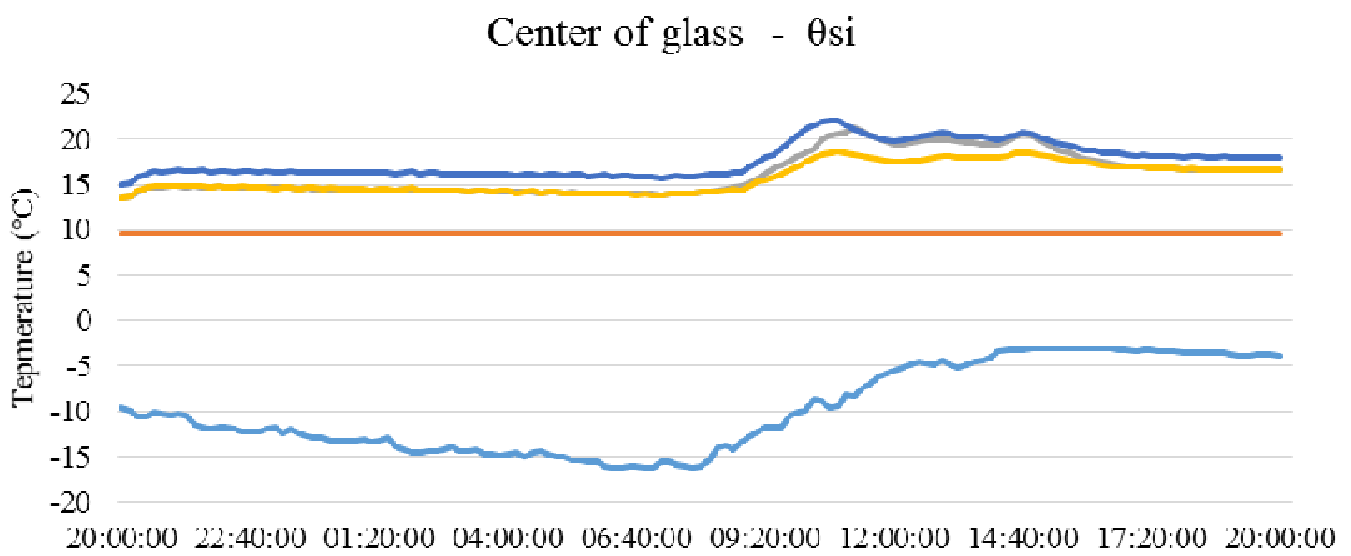

Time (h)

outdoor air temperature $-\mathrm{A}-\mathrm{B}-\mathrm{C}-\mathrm{SIN}$ req. 


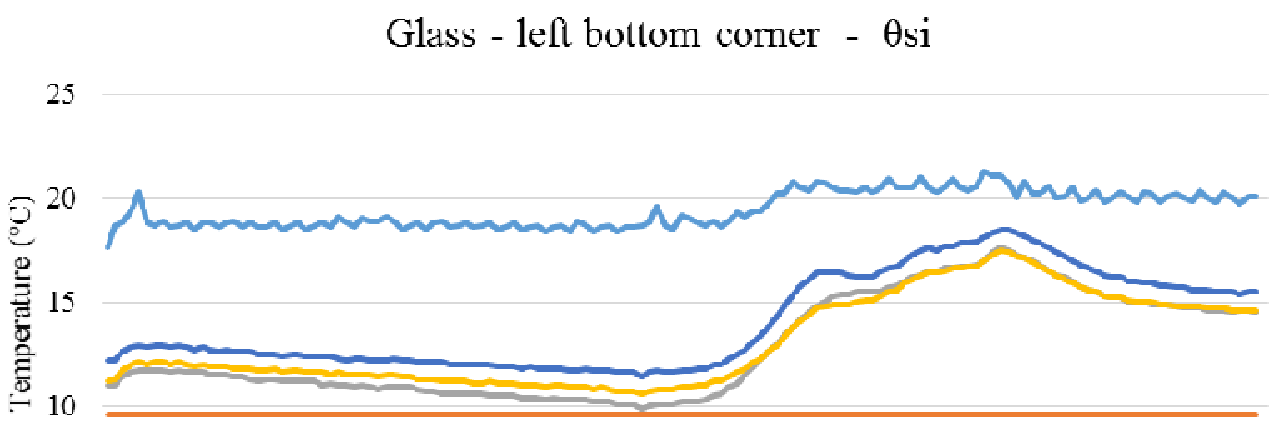

5

20:00:00 22:40:00 01:20:00 04:00:00 06:40:00 09:20:00 12:00:00 $14: 40: 00 \quad 17: 20: 00 \quad 20: 00: 00$ Time (h)

-indoor air temperature $=\mathrm{A}-\mathrm{B}=\mathrm{C} \longrightarrow \mathrm{STN}$ req. temp.

Glass - bottom - $\theta$ si

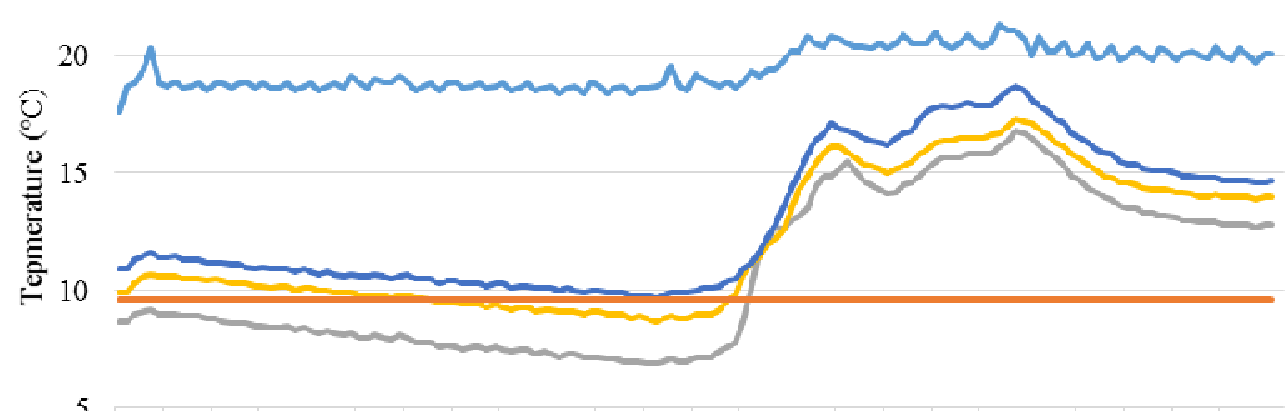

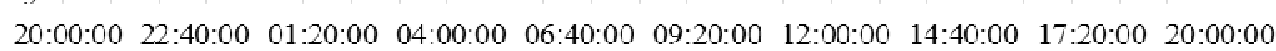
Time (h)

-indoor air temperature $=\mathrm{A}=\mathrm{B}=\mathrm{C}=\mathrm{STN}$ req. temp.

Frame - bottom - $\theta$ si

25

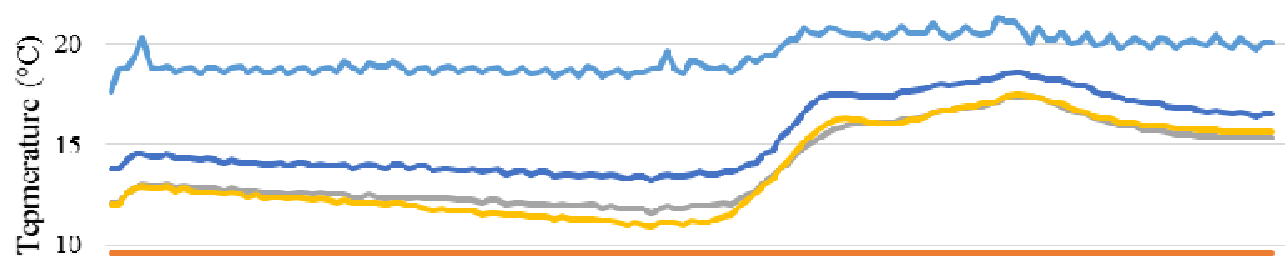

5

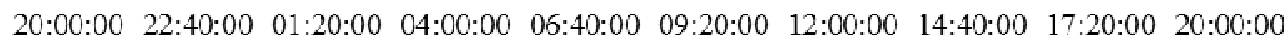
Time (h)

indoor air temperature $-\mathrm{A} \longrightarrow \mathrm{B}-\mathrm{C} \longrightarrow$ STN req. temp. 

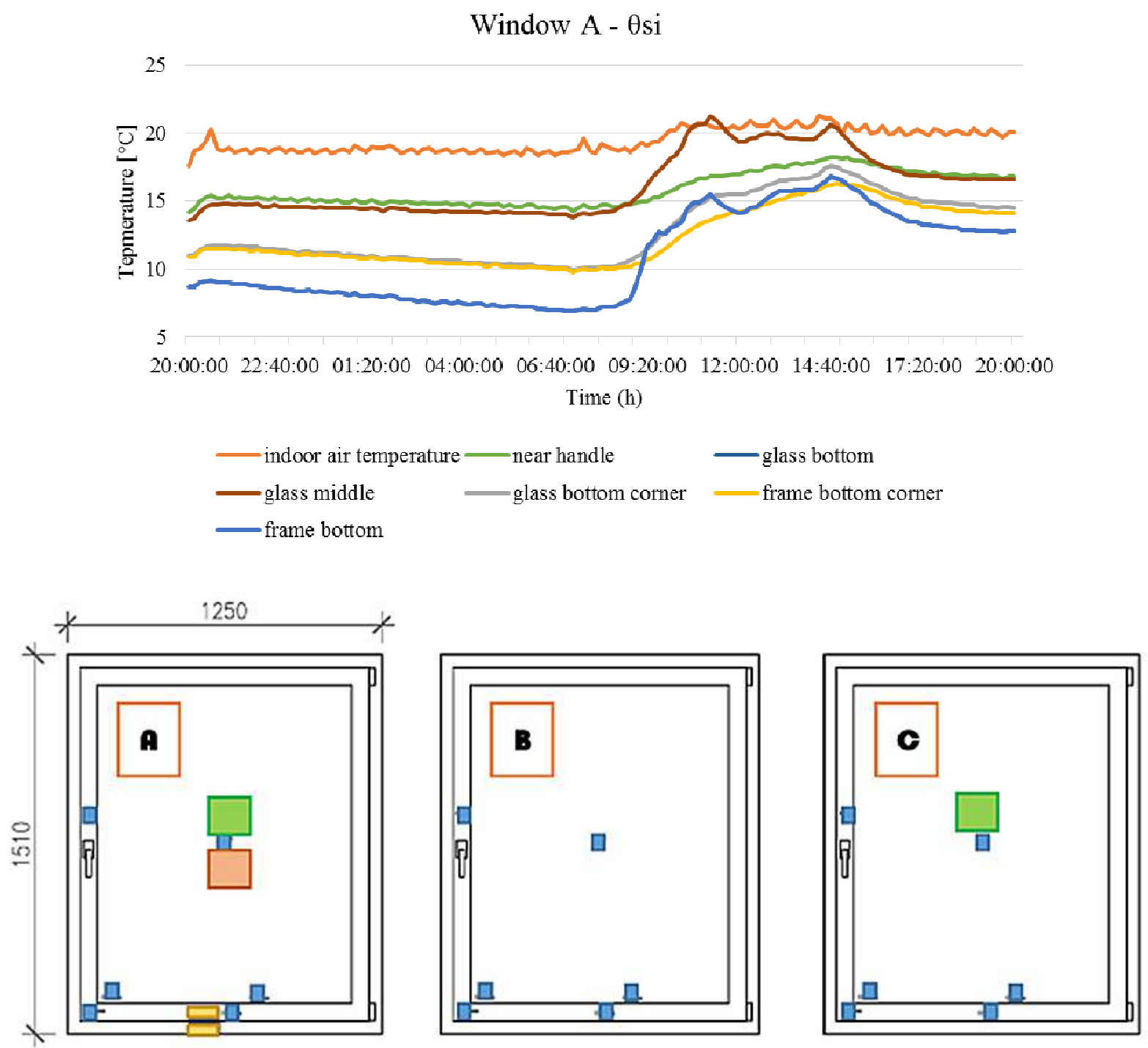

Fig. 3: Processed experimental results from windows, for publications [8].

Fig. 3 (bottom) shows a sensor placement scheme (view from inside). The thermocouples from both sides are marked in blue. HPF are placed from inside. The green marked ones are with measuring temperature, the orange ones do not measure the temperature. The yellow ones are located on the window frame and sash frame.

Research of experimental south-west oriented wall fragment in original pavilion in three structural alternatives divided into five sections among columns of frame wall construction was realized in years 2011 - 2016. Purpose of the research was to monitor temperature and humidity recorded with assistance of sensors, which are placed in the layer composition from the exterior side to the interior side in various positions in the wall, mostly at the interface of materials, according to the wall structure in three height level positions. Basic dimension of the hole for experimental wall fragment was $3706 \times 2701 \mathrm{~mm}$. A horizontal section through the structure is shown in the Fig. 4 . During the whole period of experimental research of the external wall fragment for wooden houses with different composition of individual sections, the data sets were continuously collected, analysed and evaluated. The results were published several times during the previous experiment. Sample processing the results for publication is in the Fig. 5. 


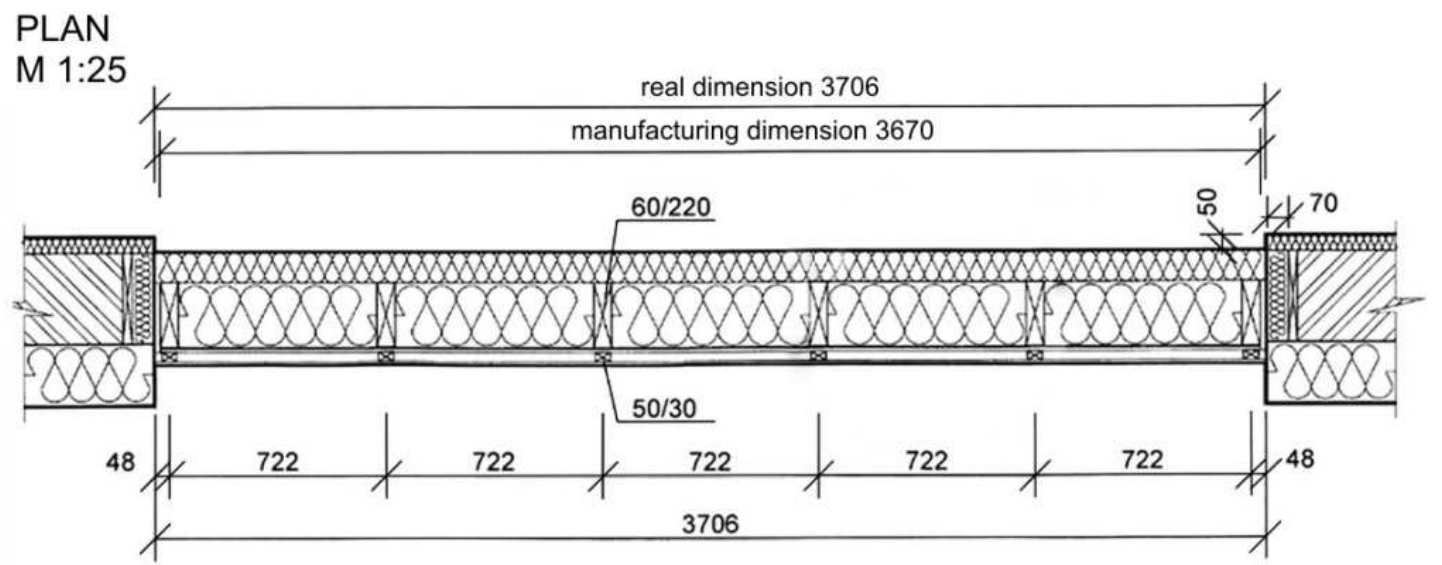

Fig. 4: Fixing the experimental wall fragment of wooden building with frame column structure into the wall.

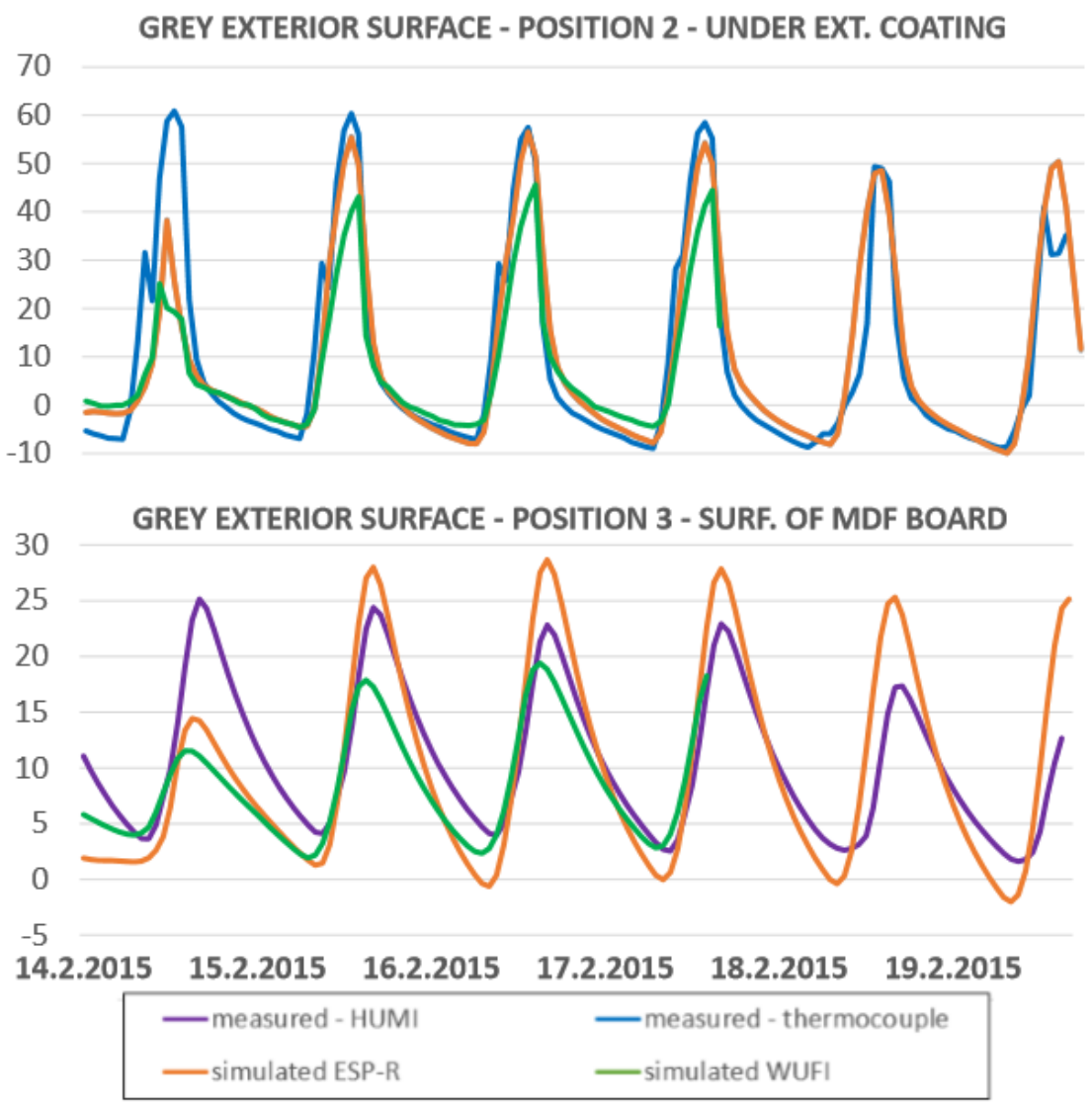

GREY EXTERIOR SURFACE - POSITION 4 - MIDDLE OF T.I.

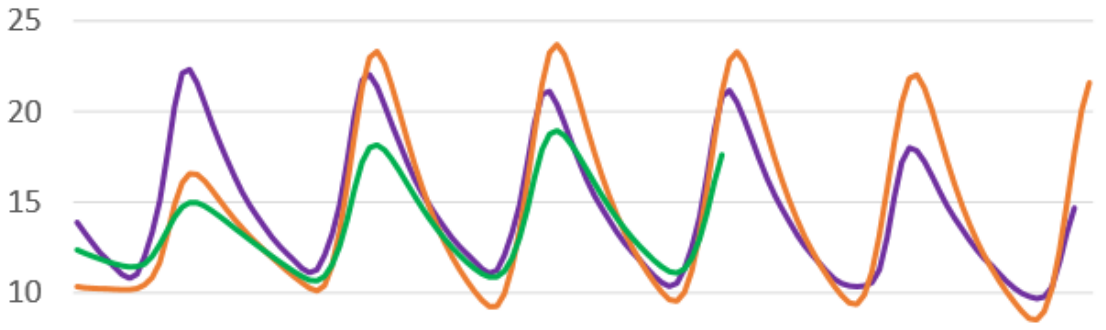

5

Fig. 5: Graphically processed experimental measurement results of the experimental wall fragment sections, chosen one week of measurements, according to the suitable boundary conditions [5]. 
Fig. 5 shows some results from experimental measurement combined with computer simulations. In previous publications from our department we can find much more about the first experimental wall fragment. Now we have included the knowledge from those measurements and prepared new experimental wall fragments (Fig. 6, 7). Testing measurements have started, the devices are controlled and in some period of time, there will be the first results from hourly, daily or monthly courses of temperature and relative humidity, or other characteristics from the individual experimental wall fragment sections.

\section{Extension and innovation of research pavilion centre for external walls of wooden buildings}

Based on experiences obtained from experimental research measurements in the pavilion with original external wall layer compositions for wooden buildings, there were designed new structures of external walls for wooden buildings and extension of this pavilion laboratory centre, by the research team lead by prof. Ing. Pavol Ďurica, CSc. And the number of pavilions increased by designing of one new experimental laboratory with south-east orientation. The original pavilion with south-west orientation was restored including new wall fragment sections.

After finishing building works and delivering new technological equipment at the end of the year 2015, an enlarged pavilion laboratory for the research of exposed walls for wooden buildings was put into the operation during the year 2016. Both pavilions of the laboratory centre are a part of the realization output of the project from structural funds "Research Centre of the University of Zilina".

The bearing structure of both experimental wall fragments consists of wooden pillars - skeleton structure, which separates them into 5 sections of the same width about $0.72 \mathrm{~m}$. This is close to the typical section width in frame constructions of wooden buildings. In experimental wall fragments of both pavilions are various layer structures suitable for building envelopes of wooden buildings. They differ from each other in particular by the type of façade surface finish. The structures are designed as simple log structures or as sandwich types. Some of them are relatively complicated, that means they match either current used wall structures of wooden buildings or they are designed with a vision of maximizing the parameters of their thermal insulating ability. In the experimental wall fragment structures we can find ventilated façade with wooden facing or parts with plaster. Each section allows creating of new individual structure designed according to the need of research or practice. Individual structures included in experimental wall fragment sections were designed so that they fulfil requirements of target parameters for external walls according to STN 73 0540-2:2012, possibly they reach higher values.

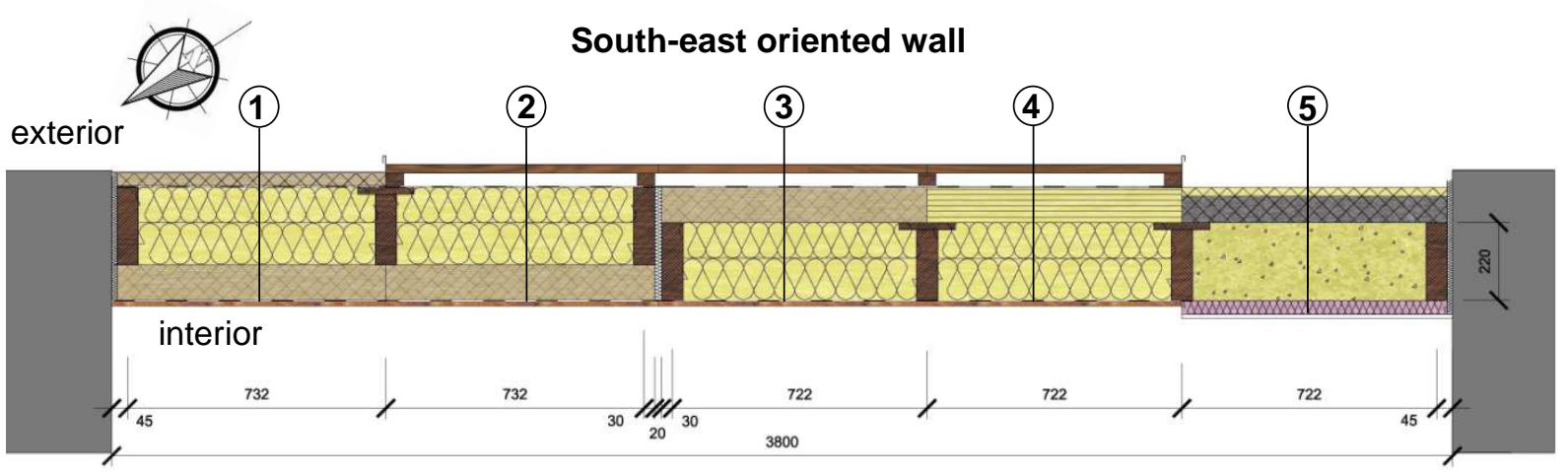

Fig. 6: Experimental wall fragment structure with orientation south-east.

The south-east experimental wall fragment (Fig. 6) consists of following layers (from exterior to interior side):

- Section no. 1:

- silicone plaster WEBER OR1E, thickness $2 \mathrm{~mm}$,

- WEBER THERM LEPARM with supporting glass fibre mesh,

- wood-fibre insulating board STEICO PROTECT, thickness $40 \mathrm{~mm}$,

- intelligent vapour membrane ISOVER VARIO KM DUPLEX UV,

- soft insulating board from glass fibres with longitudinal orientation ISOVER MULTIMAX 030, thickness $220 \mathrm{~mm}(120+100 \mathrm{~mm})$, 
- wood-fibre insulating board STEICO PROTECT, thickness $100 \mathrm{~mm}$,

- intelligent vapour membrane ISOVER VARIO KM DUPLEX UV,

- MDF board $3 \mathrm{P}+\mathrm{D}$, thickness $12 \mathrm{~mm}$.

- Section no. 2:

- wooden cladding from rustic profile $28 / 160 \mathrm{~mm}$ spliced by tongue and groove, with impregnation coating SIKKENS CETOL,

- ventilated air gap, thickness $40 \mathrm{~mm}$, created by laths $60 / 40 \mathrm{~mm}$,

- intelligent vapour membrane ISOVER VARIO KM DUPLEX UV,

- soft insulating board from glass fibres with longitudinal orientation ISOVER MULTIMAX 030, thickness $220 \mathrm{~mm}(120+100 \mathrm{~mm})$,

- wood-fibre insulating board STEICO PROTECT, thickness $100 \mathrm{~mm}$,

- intelligent vapour membrane ISOVER VARIO KM DUPLEX UV,

- MDF board $3 \mathrm{P}+\mathrm{D}$, thickness $12 \mathrm{~mm}$.

- Section no. 3:

- wooden cladding from rustic profile $28 / 160 \mathrm{~mm}$ spliced by tongue and groove, with impregnation coating SIKKENS CETOL,

- ventilated air gap, thickness $40 \mathrm{~mm}$, created by laths $60 / 40 \mathrm{~mm}$,

- intelligent vapour membrane ISOVER VARIO KM DUPLEX UV,

- wood-fibre insulating board STEICO PROTECT, thickness $100 \mathrm{~mm}$,

- soft insulating board from glass fibres with longitudinal orientation ISOVER MULTIMAX 030, thickness $220 \mathrm{~mm}(120+100 \mathrm{~mm})$,

- intelligent vapour membrane ISOVER VARIO KM DUPLEX UV,

- MDF board $3 \mathrm{P}+\mathrm{D}$, thickness $12 \mathrm{~mm}$.

- Section no. 4:

- wooden cladding from rustic profile $28 / 160 \mathrm{~mm}$ spliced by tongue and groove, with impregnation coating SIKKENS CETOL,

- ventilated air gap, thickness $40 \mathrm{~mm}$, created by laths $60 / 40 \mathrm{~mm}$,

- intelligent vapour membrane ISOVER VARIO KM DUPLEX UV,

- façade board from basalt fibre ISOVER TF PROFI, thickness $100 \mathrm{~mm}$,

- soft insulating board from glass fibres with longitudinal orientation ISOVER MULTIMAX 030, thickness $220 \mathrm{~mm}(120+100 \mathrm{~mm})$,

- intelligent vapour membrane ISOVER VARIO KM DUPLEX UV,

- MDF board $3 \mathrm{P}+\mathrm{D}$, thickness $12 \mathrm{~mm}$.

- Section no. 5:

- silicone plaster WEBER HN8C, thickness $2 \mathrm{~mm}$,

- WEBER THERM LEPARM with supporting glass fibre mesh,

- façade sandwich insulating board ISOVER TWINNER, thickness $100 \mathrm{~mm}(20 \mathrm{~mm}$ board from basalt fibre $+80 \mathrm{~mm}$ board from graphite polystyrene),

- blown insulation from glass fibre ISOVER INSULFIT, thickness $220 \mathrm{~mm}$,

- insulating phenolic board KINGSPAN KOOLTHERM K5, thickness $40 \mathrm{~mm}$,

- thin-layer interior plaster WEBER, thickness $4 \mathrm{~mm}$.

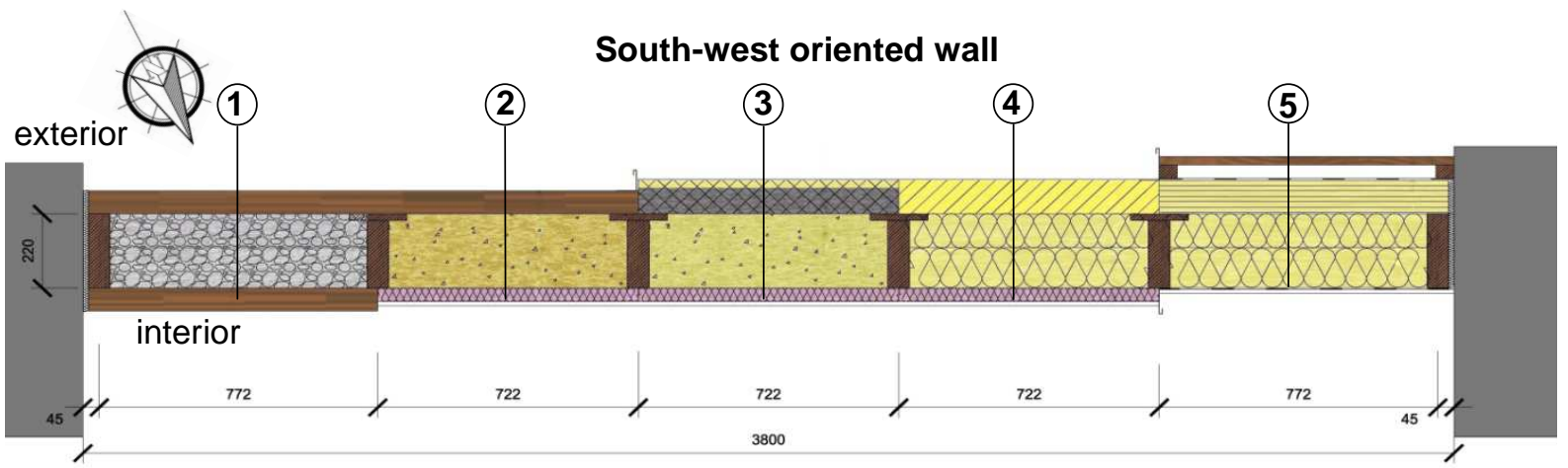

Fig. 7: Experimental wall fragment structure with orientation south-west. 
The south-west experimental wall fragment (Fig. 6) consists of following layers (from exterior to interior side):

- Section no. 1:

- façade rustic profile from massive $68 / 160 \mathrm{~mm}$ spliced by tongue and groove, with impregnation coating SIKKENS CETOL,

- insulating fleece, thickness $220 \mathrm{~mm}(120+100 \mathrm{~mm})$,

- façade rustic profile from massive $68 / 160 \mathrm{~mm}$ spliced by tongue and groove, with impregnation coating SIKKENS CETOL.

- Section no. 2:

- façade rustic profile from massive $68 / 160 \mathrm{~mm}$ spliced by tongue and groove, with impregnation coating SIKKENS CETOL,

- blown insulation from basalt fibre ISOVER GRANULATE, thickness $220 \mathrm{~mm}$,

- insulating phenolic board KINGSPAN KOOLTHERM K5, thickness 40 mm,

- thin-layer interior plaster WEBER, thickness $4 \mathrm{~mm}$.

- Section no. 3:

- silicone plaster WEBER OR1E, thickness $2 \mathrm{~mm}$,

- WEBER THERM LEPARM with supporting glass fibre mesh,

- façade sandwich insulating board ISOVER TWINNER, thickness $100 \mathrm{~mm}(20 \mathrm{~mm}$ board from basalt fibre $+80 \mathrm{~mm}$ board from graphite polystyrene),

- blown insulation from glass fibre ISOVER INSULFIT, thickness $220 \mathrm{~mm}$,

- insulating phenolic board KINGSPAN KOOLTHERM K5, thickness 40 mm,

- thin-layer interior plaster WEBER, thickness $4 \mathrm{~mm}$.

- Section no. 4:

- silicone silicone plaster WEBER OR1E, thickness $2 \mathrm{~mm}$,

- WEBER THERM LEPARM with supporting glass fibre mesh,

- façade board of glass fibre ISOVER CLIMA 34, thickness $100 \mathrm{~mm}$,

- soft insulating board from glass fibres with longitudinal orientation ISOVER MULTIMAX 030, thickness $220 \mathrm{~mm}(120+100 \mathrm{~mm})$,

- insulating phenolic board KINGSPAN KOOLTHERM K5, thickness $40 \mathrm{~mm}$,

- thin-layer interior plaster WEBER, thickness $4 \mathrm{~mm}$.

- Section no. 5:

- wooden cladding from rustic profile $28 / 160 \mathrm{~mm}$ spliced by tongue and groove, with impregnation coating SIKKENS CETOL,

- ventilated air gap, thickness $40 \mathrm{~mm}$, created by laths $60 / 40 \mathrm{~mm}$,

- intelligent vapour membrane ISOVER VARIO KM DUPLEX UV,

- façade board from basalt fibre ISOVER TF PROFI, thickness $100 \mathrm{~mm}$,

- soft insulating board from glass fibres with longitudinal orientation ISOVER MULTIMAX 030, thickness $220 \mathrm{~mm}(120+100 \mathrm{~mm})$,

- intelligent vapour membrane ISOVER VARIO KM DUPLEX UV,

- MDF board $3 \mathrm{P}+\mathrm{D}$, thickness $12 \mathrm{~mm}$.

The interior sides of both pavilions will be finished in all sections with plasterboard fixed to the grid, possibly with the thin-layer interior plaster. To compare the influence effect of wall fragment orientation to cardinals on recorded parameters of temperature and relative humidity in the layer compositions of individual wall fragment sections, there are designed two same layer compositions in both experimental wall fragments (Fig. 6,7).

Both pavilion laboratories for external walls of wooden buildings are equipped by a highperformance air-conditioning unit (Fig. 8), which assigns needed parameters of the indoor environment in given space according to actual requirements. 


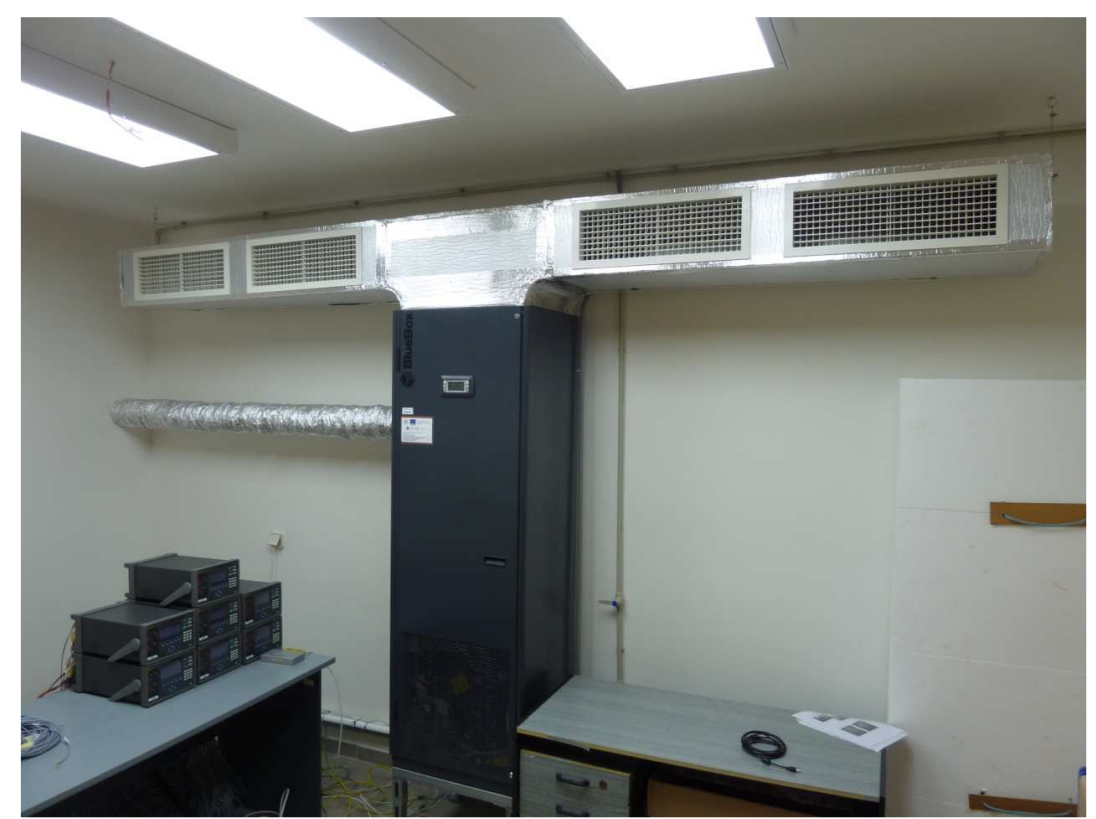

Fig. 8: View at the air-conditioning unit for assignment of indoor environment, multi-channel digital dataloggers and multimetres Hydra III. (placed on the table) [1].

\section{Temperature and humidity recording in experimental wall fragment structures}

Experimental wall fragment compositions are defined as inhomogeneous structures (from the point of view of thermal technics). With respect to the initiated fact, all the temperature and relative humidity sensors are situated. They are in individual wall fragment sections and in the area of thermaltechnical weakened part of the structure - in so-called thermal bridges.

Temperatures at the individual places in layer formation of experimental wall fragment are monitored by NTC thermal resistor with the accuracy of $\pm 0.2 \mathrm{C}$. The relative humidity is measured by capacity sensor with the accuracy of $\pm 2 \%$. Transmission of a signal to the multi-channel digital recorder and multimeter Fluke Hydra III is provided by a shielded cable. Recording of physical parameters is performed at specified time intervals. Thus generated data files are stored on the data storage. In total about 400 sensors of both types is marked according to their positions in individual pavilions and in the composition of the experimental wall fragment sections. Sensors characterized in such way are easy to control, remove, replace or re-use in case of layer position change of individual sections. In addition to the parameters obtained from the sensors in layer compositions, the temperature and relative humidity of indoor air in the middle of the room is recorded.

Exterior boundary climate conditions are monitored by the detached experimental weather station, which is placed on the roof of the building. It measures, records and sends data into the central device in the laboratory in specified time periods. Measured values are temperature and external air humidity, wind speed and direction and global solar radiation intensity.

The advantage of using data from an experimental weather station consists in the fact that for any calculations, simulation, and evaluation of measured data will be used the data files, obtained directly in the locality of measurement, which allows us to achieve more accurate results. Vision for the future should be a comparative evaluation using some reference data files from the location near Žilina - the meteorological station in Dolný Hričov and also own measurements from our experimental detached meteorological station. In view of the fact that the climate is changing gradually, incorporating the most recent values of boundary conditions into the calculation is surely a benefit of experimental outcomes and is of practical importance. The advantage is the choice of time step of recorded measured variables, which enables the unification of individual laboratory measurements.

\section{Conclusion}

Experimental pavilion laboratory centre for windows and external walls for wooden buildings with various section compositions was put into the operation in the year 2011 and innovated in the year 2015. The research principle is to measure the parameters of windows and the temperature and 
relative humidity in the cross-sectional design of exterior wall fragments in stable conditions of interior and real external climate conditions at selected time intervals. Based on data collection, analysis and evaluation on the basis of long-term measurements we will be able to obtain the documentation characterizing performance regime of windows and various types of exterior wall compositions suitable for wooden houses, throughout the year.

\section{Acknowledgement} formation.

The research was supported by the grant project VEGA no. 1/0945/16 as well as the article

Thank to Mr. Kajaba from Slovak Hydrometeorological Institute for his help and processed documents.

\section{References}

[1] JAKUBČíK, M. - RYBÁRIK, J.: Digitálny archív z výstavby budovy VC UNIZA - stavebný dozor. KPSU SVF UNIZA, 2015.

[2] ĎURICA, P. - RYBÁRIK, J. - BAĎUROVÁ, S. - CANGÁR, M.: Experimentálne merania obalových konštrukcií v Laboratórnom centre KPSU SvF v Žiline. In: Drevostavby - IV. vedecká konferencia s medzinárodnou účast'ou, 2. - 3. 6. 2011, Terchová, SR, ISBN 97880970171-9-4, pp. 173 - 178.

[3] ĎURICA, P. - ŠTÚŇOVÁ, M. - PONECHAL, R.: Dlhodobé testovanie tepelnotechnických parametrov lahkej obvodovej steny na báze dreva = Long time testing of temperature parameters of wooden lightweight external walls. In: STRUCTURA stavební trendy 2013: ekologie, energetika, bezpečnost, udržitelnost : 3. ročník mezinárodní stavební konference, Ostrava 7. - 8. 11.2013, sborník prací ke konferenci. Ostrava VŠB - Technická univerzita, 2013, ISBN 978-80-248-3236-4.

[4] ŠUŠTIAKOVÁ, M. - ĎURICA, P. - PONECHAL, R. - CANGÁR, M.: Comparison of experimental and computational characteristics of light perimeter walls of wooden buildings. In: 6th International Conference on Contemporary Problems of Architecture and Construction: $24^{\text {th }}-27^{\text {th }}$ June 2014, Ostrava, Czech Republic [CD-ROM]. Ostrava: VŠB - Technical university of Ostrava, 2014, ISBN 978-80-248-3147-3, 6 p.

[5] JURAS, P. - PONECHAL R.: Measurement of lightweight experimental wall and comparison with different simulation programs. In: Applied mechanics and materials: advanced architectural design and construction: special topic volume with invited peer reviewed papers only. ISSN 1660-9336, Vol. 820 (2016), pp. 262 - 269.

[6] ĎURICA, P. - Poruchy budov, Diagnostika a sanácia, 1. vydanie - Žilina, Žilinská univerzita, 2012, ISBN 978-80-554-0561-2, $244 \mathrm{p}$.

[7] KORENKOVÁ, R., et al.: Drevostavby, Konštrukcie budov 4, 1. vydanie - Žilina, Žilinská univerzita, 2009, ISBN 978-80-554-0078-5, $194 \mathrm{p}$.

[8] DURICA, P. - JURAS, P. - STAFFENOVA, D.: Results of long-term experimental testing of windows for low energy houses In: $4^{\text {th }}$ International Conference on Applied Technology, ATF 2016, 15 - 17 September 2016, Leuven, Belgium.

[9] ĎURICA, P. - ĎURINÍKOVÁ, M. - RYBÁRIK, J. - ŠTAFFENOVÁ, D.: Long time testing of temperature parameters in selected windows. In: Advanced materials research, Vol. 855, 2014, pp. 81 - 84 . 